\title{
Service recovery, customer satisfaction and customer loyalty: evidence from Malaysia's hotel industry
}

\author{
Boon Liat Cheng and Chin Chuan Gan \\ Sunway University, Bandar Sunway, Malaysia \\ Brian C. Imrie \\ KDU Penang University College, Penang, Malaysia, and \\ Shaheen Mansori \\ Malaysia University of Science and Technology, Petaling Jaya, Malaysia
}

Malaysia's hotel industry

Received 21 September 2017

Revised 8 January 2018 22 April 2018

17 September 2018

Accepted 16 October 2018

\begin{abstract}
Purpose - The purpose of this study is to investigate the impact of service recovery dimensions on customer satisfaction and, subsequently, on customer loyalty in the context of the hotel industry.

Design/methodology/approach - A self-administered questionnaire was distributed to 500 respondents who had the experiences of staying in the hotels in Malaysia. The structural equation modelling technique was used to study the relationship between the model and the developed hypotheses.
\end{abstract}

Findings - The findings revealed that service recovery dimensions are significantly related to customer satisfaction and have a positive relationship between customer satisfaction and customer loyalty.

Practical implications - As the main sector in the hospitality business, hotels play a vital role in the tourism industry. Therefore, the developments in tourism and hotels go hand in hand, as they are mutually dependent on each other. With significant yearly developments in the tourism industry and at a constant rate, hotel operators should reconsider their business strategies to achieve customer loyalty and sustain their businesses. In view of that, the findings of this study not only benchmarks better hotel services but also provides an improved understanding of service recovery that will effectively aid hotel operators in handling service failures; otherwise, customer dissatisfaction may occur if poor service recovery strategies are implemented.

Originality/value - The intense competition in the service industry has driven companies to place extra attention on service recovery so as to ensure continuous success. With a yearly significant development in the tourism industry at a constant rate, hotel providers (one of the major beneficiaries) are driven to reconsider their business strategies to achieve customer loyalty and sustain their business.

Keyword Customer loyalty

Paper type Research paper

\section{Introduction}

The hotel industry has been exponentially growing and is one of the most significant contributors to the advancement of the tourism industry. Over six decades, tourism continues to expand and diversify, becoming one of the fastest-growing and largest economic sectors in the world. International tourism has developed at a pace more rapid than world trade, representing 7 per cent of the world's goods and services export in 2015; an increase of 1 per cent compared to 2014. In 2015, international tourist arrivals amounted

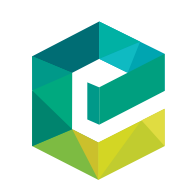

International Journal of Quality and Service Sciences 11 No. 2, 2019 Emerald Publishing Limited 1756-669X DOI 10.1108/IJQSS-09-2017-0081 
IJQSS

11,2

to 1,186 million, an increase of 52 million from 2014. This is at a constant increase of a minimum of 4 per cent since 2010 (UNWTO, 2017). By region, America and Asia and the Pacific have both led the growth of 6 per cent in international tourist arrivals, followed by Europe at 5 per cent. With the expansion of demand and supply of the tourism sector comes an improvement in the GDP and employment rate. International tourism contributed 10 per cent (US\$7,170.3bn) of the global GDP in 2015; with the forecasted annual rise of 4 per cent, by 2026 , this will amount to US $\$ 10,986.5 \mathrm{bn}$. Jobs supported by tourism amounted to 9.5 per cent of the total global employment and is expected to grow 2.5 per cent per annum by 2026 (WTTC, 2016). The significance of tourism on the global scale has prompted countries and business operators to place more emphasis on this lucrative business.

One of the major beneficiaries in tourism (the players in the hospitality industry) must stay innovative and vigilant to stand out among the mushrooming rivals. The need for hotel operators to be more attentive while handling their guests has become crucial to stay competitive in the hotel industry, as customer expectations are ever-rising. It is imperative for hotel operators to continue incorporating new service elements into their service delivery. Hotel operators should anticipate that different guests always come with various levels of service expectations. However, it is important that hotels should first satisfy the basic needs of customers instead of placing too much emphasis on supplementary services. Customers tend to be dissatisfied if the perceived service quality is not up to their expectations, which eventually affects customer relationships in the long-term. Furthermore, without a proper and well-structured service recovery procedure to handle service failures, companies are at risk of losing their customers because of the inability of meeting customer expectations (Giese and Cote, 2000; Mansori et al., 2014, p. 204). Eventually, hotel operators will be the ultimate losers because dissatisfied customers will not visit the same hotel again and in worst case scenario will provide negative feedbacks on social media.

One of the ideal methods to strengthen customer relationship is by listening to their complaints. Customer voices are often received in the form of complaints reported to the hotel because of service failure occurrences. The importance and value of customer complaints about an organisation were further highlighted by Dolinsky (1994). It is imperative to include customer complaints or feedbacks in the service recovery process, as supported by Schoefer and Ennew (2004) who stated that customer complaints or feedbacks are important sources of ideas that help foster the growth of an organisation by enhancing the current services provided to the customers. The management of service failure is crucial because if mishandled, it can be detrimental to a hotel. The main objective of managing service failure is to minimise the negative impact of a bad experience that a customer suffers and ultimately, encourage customer loyalty when the service failure has been rectified with care. Tax et al. (1998) suggested that service recovery affects customer outcomes in terms of regaining customer satisfaction, repurchase intentions and positive word-of-mouth.

Despite the significant impact of service recovery procedures to bring back customers to their satisfied status, not many studies are present in this field and most of the current literature concentrates on customer viewpoints in measuring their level of satisfaction (Hui et al., 2007) rather than on their perception towards the service recovery procedures. For that reason, it is essential to deeply explore customer perceptions of service recovery, customer satisfaction and customer loyalty.

\section{Literature review}

An extensive review has been conducted of the extant literature to elaborate on the existing understanding of the dependent relationship between service recovery, tourist satisfaction and its consequent impact upon loyalty. In what follows, a review of the customer 
satisfaction literature is undertaken and how it converges with the concept of tourist satisfaction.

\section{Tourist satisfaction}

Customer satisfaction has been a popular subject for research since customer responses determine the long-term customer relationship, which can subsequently lead to the sustainability of a business (Anderson et al., 2004; Fornell et al., 1996; Hackl and Westlund, 2000). With the wide proliferation of service provision, there are rarely any occurrences of monopolistic service provisions where customers have few or close to zero say on their purchases. Numerous researchers have attempted to define satisfaction, however, it can be defined broadly as "the consumer's response to the evaluation of the perceived discrepancy between prior expectations and the actual performance of the product as perceived after its consumption" (Tse and Wilton, 1988, p. 204). This response to prior expectations is referred to as the disconfirmation paradigm (Oliver, 1999) and is at the centre of the related satisfaction and broader service quality constructs. Giese and Cote (2000) determined three general components of satisfaction as the basis of its definition:

- satisfaction is an emotional response;

- a response that refers to a definite focus; and

- a response that is regulated by restricted time.

Within the recent service marketing literature this understanding is further expanded wherein customer satisfaction is depicted as being constructed of perceived image (ChienHsiung, 2011), service quality, and perceived value (Mohajerani and Miremadi, 2012). In the context of hospitality and tourism, customers are tourists with the role of utilising and experiencing the goods and services purchased. Satisfaction and customer loyalty are key determinants in the success of the market concept implementation. Tourists who are satisfied are more likely to have the intention of revisiting and repurchasing if the service provider achieves or exceeds their expectations (Shah Alam and Mohd Yasin, 2010). Notably, fulfilment and exceeding expectations (i.e. a positive service quality evaluation) leads to greater satisfaction, generating greater retention of customers (Jones and Farquhar, 2003; Ranaweera and Prabhu, 2003). Concurring with the marketing literature, Kandampully and Suhartanto (2000) found within the tourism industry that image is highly influential in establishing a hotel guest's repurchase intentions and activating positive word-of-mouth. A hotel's image, which can directly indicate the quality of a customer's service experience, can be influential on customers' perceptions of value and satisfaction, which, in turn, affects their behavioural intentions (Ryu et al., 2008). Despite all the research establishing the link between quality evaluation, service provider image and satisfaction an examination of the pleasurable and favourable responses of tourists toward a service provider during service recovery (after the service provider failed to reach tourist expectations for the first time) are lacking. This study examines the effect of the service recovery process on tourist satisfaction and loyalty within the hotel industry.

\section{Service recovery}

According to Bitner et al. (1990), service failure occurs if the customer has an unpleasant experience or feels dissatisfied with the service. A study by Hart et al. (1989) suggested that it can be a challenge for the enterprise to provide consumers with a consistently satisfactory service product. Fortunately, in the event of service failure, service recovery has been acknowledged as one of the most significant determinants of customer satisfaction and 
IJQSS

11,2

loyalty (Komunda and Osarenkhoe, 2012; Melián-González et al., 2013; Wen and Geng-qing Chi, 2013) Cobanoglu, and Okumus, 2016. According to Grönroos (2007), service recovery refers to the action taken by a service provider in response to receiving a customer complaint because of service failure.

As a result, it is important that a comprehensive service recovery procedure is developed to effectively counter the two major challenges (Forrester and Maute, 2013; Mansori et al., 2014). Accordingly, astute hospitality providers increasingly include service recovery into company policy to address customer dissatisfaction (Melián-González et al., 2013).

One service recovery strategy may not fit all customers and an ineffective service recovery can be costly to the firm. In an increasingly connected socio-cultural environment, it is known that disappointed customers will spread their bad experience to another ten to twenty people depending on the intensity of their dissatisfaction (Mansori et al., 2014). The level of familiarity or experience (Oliver, 1999) in certain service products plays an important role in shaping customer expectations. Similarly, familiarity also informs consumer perceptions of both new and experienced customers on what constitutes acceptable service recovery processes and outcomes. Consumer expectations are likely to be formed in the early stages of service provision as well as within the recovery stage immediately after a service failure (Hazée et al., 2017; Miller et al., 2000; Murphy et al., 2015). Being aware of these expectations is critical for addressing them and achieving a satisfied and loyal customer base.

At the heart of many recent definitions of customer satisfaction is an emotional response of pleasurable approval for a satisfactory outcome, or alternatively, disdain in the event of dissatisfaction. Hoffman and Kelley (2000) highlighted that customers engaged in consuming a service invest monetary value, time, (emotional) energy and physical costs in accessing that service. If the outcome is dissatisfaction with the initial service objective, the customers may then seek a fair recompense for the financial and personal investments made. In the event where the service response is judged as insufficient, a customer may feel aggrieved and react in an emotionally charged way; with the intensity determined by their prior experience with the service context. Thus, service recovery policy comes in place where formal methods or steps must be crafted to address service failures (Grönroos, 2007) and manage emotional response. The understanding of what constitutes a just outcome is important to the crafting of such an effective service recovery plan, and this needs to be woven into any service recovery process. The following discussion summarises the current state of knowledge in this area and sets the stage for the research agenda examining how service recovery influences perceptions of fairness and satisfactory customer outcomes in the hotel industry.

\section{Perceived justice}

To fully comprehend the service recovery process, the justice theory is essential; it has been consistently used as a guide for monitoring the service recovery process (McColl-Kennedy and Sparks, 2003; Sparks and McColl-Kennedy, 2001). The fundamental idea for the justice theory is that customers are expected to be impartially treated in the service recovery process, and if they perceive that they were treated unjustly, negative responses will be produced which will affect their satisfaction and future behaviour. This theory has been implemented as a remedy for restoring customers' feelings of justice in a loss, and has concurrently improved the relationship between customers and service providers.

Fairness is used by the customer as the underlying basis to judge their connection with the service provider (Martínez-Tur et al., 2006). Furthermore, Clemmer and Schneider (1996) proclaimed that the perception of justice is associated with customer satisfaction and 
constantly appears in the consumption experience (Kim et al., 2009; Maxham and Netemeyer, 2002). The justice theory consists of three factors, as discussed in this research: distributive, procedural and interactional fairness (Choi and Choi, 2014; Mansori et al., 2014; McColl-Kennedy and Sparks, 2003; Siu et al., 2013).

\section{Distributive justice}

Distributive justice is sometimes known as the justice outcome in the service recovery context. Distributive justice is concerning the impartiality of the remedy (Bugg Holloway et al., 2009). Definitions of the term includes "equity" as well as concepts such as "need" and "equality". Concerns regarding the measurement of distributive justice arise because of the potential ambiguity among customers in distinguishing between equity, need and equality, as well as the difficulties to assess input and output from similar viewpoints of both service providers and customers (Mattila and Patterson, 2004).

Previous studies have shown the significance in the role of distributive justice regarding service recovery. Distributive justice in service recovery is attained when a customer receives what they would have received before the service failure occurred. When a customer thinks that the remedy is reasonable and fair, it will restore he/she perceived distributive justice (Kuo and Wu, 2012; Siu et al., 2013). Empirical studies showed that reasonable tangible outcomes will have a positive effect on customer service recovery judgment (Bugg Holloway et al., 2009; Kuo and Wu, 2012; Siu et al., 2013). However, replacement, correction, reimbursement, credit and no attempt at resolution could also be potential responses to distributive injustice (Lin et al., 2011). In line with various studies, the customer perception on distributive justice (such as impartiality, needs, value and compensation of outcomes) was measured in service recovery. Therefore, to test the relationship between the possible impact of distributive justice on the level of customer satisfaction, the following hypothesis was established:

H1. Distributive justice has a positive effect on customer satisfaction towards hotel services.

\section{Procedural justice}

Procedural justice refers to the policies and procedures that any customer must go through to seek fairness. Service recovery literatures defined procedural justice as the organisation's step-by-step actions in solving problems (Ha and Jang, 2009). Procedural justice is also interpreted as the "adequacy of criteria or procedure" in decision-making (Tax et al., 1998). It is generally applied in measurement of fairness (as perceived by customers) to identify and reflect on service failures and recoveries.

Not only are companies expected to take full responsibility for the service failure, the recovery process must also be convenient, accessible and responsive for customers to seek compensation (del Río-Lanza et al., 2009). Moreover, the service recovery process must be flexible and consider customer inputs. Procedural justice includes formal operating rules, ways and tools adopted by service providers to facilitate the process so that the time needed to manage the complaints can be greatly reduced (Mattila and Patterson, 2004). Service recovery often involves numerous stages of procedures and processes (Mattila and Patterson, 2004). Past research highlighted that flexibility, accessibility, process, decision, controlling the speed of response and acceptance of responsibility are all dimensions of procedural justice (del Río-Lanza et al., 2009; Gounaris et al., 2003). Therefore, to examine the 
IJQSS

11,2

relationship between the procedural justice and customer satisfaction level the following hypothesis was developed:

H2. Procedural justice has a positive effect on customer satisfaction towards hotel services.

\section{2}

\section{Interactional justice}

Interactional justice has been widely researched regarding customer satisfaction during the occurrence of service failure or perceived injustice. Interactional justice emphasises the communication between service providers and their customers. It involves the staff of the firm who deliver the service recovery and their behaviour towards customers (Sparks and McColl-Kennedy, 2001). Interactional justice can be defined as whether the customer experienced fairness in the human interactional manner with service providers during service recovery. The impact of personal interactions in problem solving within service transactions in which prior experience can be influential on the resolution of a conflict were highlighted in previous research (Choi and Choi, 2014; del Río-Lanza et al., 2009).

Previous studies have shown that courtesy, honesty, offering an explanation, empathy, endeavours and apologies are the dimensions of interactional justice (Baloglu et al., 2010; Komunda and Osarenkhoe, 2012; Lin et al., 2011). Therefore, to investigate the relationship between the interactional justice and customer satisfaction level the following hypothesis was made:

H3. Interactional justice has a positive effect on customer satisfaction towards hotel services.

\section{Customer loyalty}

It is well established in the literature that customer satisfaction is part of the requirements for developing their loyalty. Organisations must be good at handling arising problems and properly solve them so that the firm is able to retain this relationship (Morgan and Hunt, 1994) Past studies have shown that effective service recovery will induce customer loyalty (Choi and Choi, 2014; Komunda and Osarenkhoe, 2012). Previous service recovery research has found that customer loyalty is a function related to perceived fairness during the restoration of service failure (Tax et al., 1998). Although a significant amount of studies have been conducted regarding service recovery, research gaps still remain in the literature.

Basically, trust is the major resistance or impediment for firms in developing customer relationships (Mansori and Vaz, 2014; Morgan and Hunt, 1994). A few studies have also found that the perception of fairness in a service recovery is crucial for influencing trust, which will subsequently lead to customer loyalty (Tax et al., 1998). Chebat and Slusarczyk (2005) suggested that if the customer does not respond to the service recovery, firms are given the choice to ignore the customer. Customer loyalty can be defined as an intensely involved commitment to consistently re-buy or re-patronise goods from the same service providers in future. It can cause repetitive purchase of the same brand, or brand-set purchasing (Oliver, 1999). The concept of loyalty consists of two elements, which are attitudinal and behavioural aspects (Chan and Mansori, 2016; Liat et al., 2014; Oliver, 1999). On the other hand, Jacoby and Chestnut (1978) demonstrated that the customer loyalty concept refers to the attitude of customers towards the relationship between customers and sellers. They further highlighted another concept that refers to loyalty; i.e. the repurchasing behaviour of customers. According to Reichheld et al. (2000), customers express their loyalty 
behaviour in different ways. Several common ways are first, re-purchase goods or services from the same seller; second, increase the frequency of their buying behaviour; and third, be a supporter and defender of the organisation. However, many research studies solely focussed on repurchasing behaviour without considering the dimension of attitude. Thus, it can be hypothesised that:

H4. Customer satisfaction has a positive effect on customer loyalty for the hotel.

Based on the past studies reviewed, the proposed conceptual framework is presented in Figure 1.

\section{Malaysian versus international tourists}

Customer nationality plays a major role since an individual's national identity is highly associated with cultural dimensions (Steenkamp and Geyskens, 2012). The role of country of origin in the relationship between satisfaction and loyalty has been studied from multiple aspects within various industries (Berezan et al., 2013; Pantouvakis and Bouranta, 2013). Customers from diverse nationalities may have different levels of satisfaction and loyalty because of varied cultural backgrounds and diversified experiences. The differences in perception forming of the tourism image (comprising of tourism activities, food and lodging) depend on various socio-demographic features of tourists from assorted nationalities.

A study was conducted by Van Den Haak (2015) on satisfaction and loyalty levels of customers from Germany, France and The Netherlands. The findings illustrated that loyalty is stronger among German customers than French and Dutch customers (Van Den Haak, 2015). Berezan et al. (2013) accomplished a research on the relationship between hotel customers' satisfaction, loyalty and implementation on the green practice initiative. The results indicated that customers from various nationalities (Mexicans, Americans and others) have different levels of satisfaction and loyalty. As a result, it is highly advisable for companies that deal with multinational customers to provide varied strategies based on different product categories and customer nationalities (Pantouvakis and Bouranta, 2013). After a review of various literatures, it was identified that local and international tourists may have different level of satisfaction and loyalty; thus, whether the individual is Malaysian or International ethnicity plays a moderating role in this research. To test the moderating role of nationality on the relationship between satisfaction and loyalty, the following hypothesis has been developed:

H5. The country of origin (Malaysian verses international) moderates the relationship between satisfaction and loyalty.

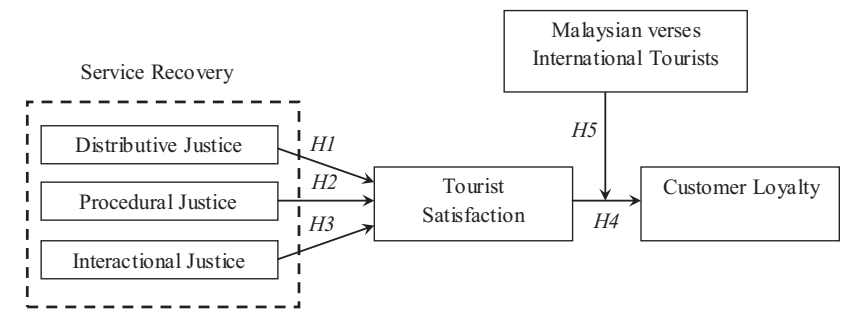

Figure 1. Research model 
IJQSS

11,2

\section{Methodology}

A self-administered questionnaire was developed as the data collection instrument for this study. The service recovery consists of three dimensions: distributive justice (four items), procedural justice (four items) and interactional justice (four items). As for customer satisfaction, the measurement used was adapted from the scale developed by Kuo et al. (2013), and operationalised with four items based on tourists' overall satisfaction towards hotel services. Customer loyalty was based on the seven-item scale by Skogland and Siguaw (2004), which was applied based on customers' willingness to recommend, revisit intention and provide positive word-of-mouth. All items used in this study are presented in Appendix. Moreover, all other measurement items for the constructs were assessed using a five-point Likert scale from 1 = Strongly Disagree to $5=$ Strongly Agree.

In this study, the term "tourists" refers to domestic or foreign visitors staying away from home for one or more nights and for various purposes including holiday, leisure and recreation, business, heath, education, etc. (UNWTO, 2017). The targeted population includes Malaysians and international tourists. Five hundred questionnaires were distributed at the entry/exit points of Kuala Lumpur International Airport and Kuala Lumpur International Airport 2. The researchers approached respondents while they were waiting for their flights. After acquiring consent from respondents for their voluntary participation, an explanation for the purpose of the survey and questionnaires was given. In addition, two screening questions were asked to identify whether they had stayed in hotels within Malaysia for at least one night during their visit, and if they had experienced a certain kind of hotel service failure during their stay. For ethical reasons, the researchers guaranteed confidentiality and anonymity to the respondents who participated in this study.

With respect to data analysis, this study used a two-step approach with the use of SPSS and AMOS statistical software. At the initial stage, the confirmatory factor analysis was conducted to examine the internal consistency of the constructs employed in this study. The reliability and validity (discriminant and convergent validity) of the items were reported based on the suggestions by Hair et al. (2006). Subsequently, the structural equation modelling technique was used to examine the causal relationships in the model and hypotheses developed.

\section{Data analysis \\ Sample characteristics}

From the 500 distributed questionnaires, 58 samples were excluded, as they were not completely answered, and 442 usable ones were included for further data analysis. The profiles of respondents were presented in Table I with the use of SPSS. Table I revealed that most respondents in this study are males (55.33 per cent) and fell in the age group between 26-35 years old. Moreover, most respondents are married (55.4 per cent) and international tourists (73.1 per cent). As far as profession is concerned, most respondents are either working for a company (41.2 per cent), self-employed by having their own business (32.8 per cent) or unemployed. The statistics further revealed that most were travelling along with their family members (50.2 per cent) and have stayed at a hotel in the range of 1-3 times.

\section{Validity and reliability tests}

To address both the validity and reliability aspects of the measurement, the confirmatory factor analysis using the maximum likelihood estimation was employed to test the internal consistency of the measures and all constructs were included in this study. According to Hair et al. (2006), a model with good fit will have a goodness of fit index (GFI) of more than 0.90, Root Mean Square Error of Approximation (RMSEA) of less than 0.08, Tucker-Lewis 


\begin{tabular}{|c|c|c|c|c|}
\hline Variable & Details & Frequency & $(\%)$ & $\begin{array}{l}\text { Malaysia's } \\
\text { hotel industry }\end{array}$ \\
\hline \multirow{2}{*}{ Gender } & Male & 205 & 46.4 & \\
\hline & Female & 237 & 53.6 & \\
\hline \multirow{5}{*}{ Age } & $18-25$ years old & 88 & 19.9 & \\
\hline & $26-35$ years old & 128 & 29.0 & \\
\hline & $36-50$ years old & 86 & 19.5 & \\
\hline & $51-65$ & 72 & 16.3 & 195 \\
\hline & 66 and above & 68 & 15.4 & \\
\hline \multirow[t]{3}{*}{ Marital Status } & Single & 192 & 43.4 & \\
\hline & Married & 245 & 55.4 & \\
\hline & Divorced & 5 & 1.1 & \\
\hline \multirow[t]{2}{*}{ Nationality } & Malaysian & 119 & 26.9 & \\
\hline & Non-Malaysian & 323 & 73.1 & \\
\hline \multirow[t]{5}{*}{ Occupation } & Student & 40 & 9.0 & \\
\hline & Working for company & 182 & 41.2 & \\
\hline & Owner of a business & 145 & 32.8 & \\
\hline & Retired & 57 & 12.9 & \\
\hline & Others & 18 & 4.1 & \\
\hline \multirow[t]{4}{*}{ Travel Category } & Single Traveller & 78 & 17.6 & \\
\hline & Family & 222 & 50.2 & \\
\hline & Business & 81 & 18.3 & \\
\hline & Others & 61 & $\begin{array}{l}10.5 \\
13.8\end{array}$ & Table I. \\
\hline \multirow[t]{3}{*}{ Frequency of Travel } & 1 to 3 & 179 & 40.5 & Demographic profile \\
\hline & 4 to 5 & 137 & 31.0 & of respondents \\
\hline & More than 5 times & 126 & 28.5 & $(n=442)$ \\
\hline
\end{tabular}

index (TLI) of more than 0.90 and Comparative Fit Index (CFI) of more than 0.90. Based on the confirmatory factor analysis result for the model, $\chi^{2}=428.055$ ( $\mathrm{df}=220, p<0.001$ ), $\chi^{2} / \mathrm{df}=1.946, \mathrm{GFI}=0.922, \mathrm{RMSEA}=0.046, \mathrm{TLI}=0.955$ and $\mathrm{CFI}=0.961$, suggesting the model was fit.

As for the context of discriminant validity, this study employed the guideline suggested by Fornell and Larcker (1981) which according to them, the square root of Average variance extracted (AVE) should exceed the correlation between any other two constructs in order for the discriminant validity to be established. Based on the statistical output in Table II, all square roots of AVE exceeded the correlation between any other two constructs, thus demonstrating discriminant validity.

According to Hair et al. (2006), to access the convergent validity of the data, three criteria must be fulfilled. For example, the standardised factor loadings should be significantly

\begin{tabular}{lcccccccr}
\hline Variable & CR & FL & AVE & 1 & 2 & 3 & 4 & 5 \\
\hline Distributive Justice & 0.886 & $0.705-0.835$ & 0.67 & 0.818 & & & & \\
Procedural Justice & 0.818 & $0.656-0.767$ & 0.53 & 0.673 & $\mathbf{0 . 7 2 8}$ & & & \\
Interactional Justice & 0.836 & $0.696-0.780$ & 0.56 & 0.615 & 0.638 & $\mathbf{0 . 7 5 9}$ & & \\
Customer Satisfaction & 0.829 & $0.719-0.770$ & 0.55 & 0.700 & 0.691 & 0.716 & $\mathbf{0 . 7 4 0}$ & \\
Customer Loyalty & 0.888 & $0.685-0.801$ & 0.53 & 0.554 & 0.562 & 0.551 & 0.687 & $\mathbf{0 . 7 2 9}$
\end{tabular}

Notes: $\mathrm{CR}=$ composite reliability; $\mathrm{FL}=$ factor loading; $\mathrm{AVE}=$ average variance extracted; the diagonal entries (in Bold) represent the square root's average variance, and off-diagonals (in Italics) are the correlations between the constructs

Table II.

Test results of convergent validity and discriminant validity 
IJQSS

11,2

196

Table III.

Results of

hypotheses testing linked to the latent construct and have at least a loading estimate of 0.60 , the value of AVE must exceed 0.50 and the constructs should have a reliability score of more than 0.70 . Referring to Table II, all standardised loadings for the items were greater than 0.60 , the AVE for all constructs exceeded 0.50 and the reliability score for all constructs exceeded 0.70 ; thus, convergent validity was achieved.

\section{Structural model and hypothesis testing}

In the evaluation of the structural model, the fit statistics indicated that the research model in this study provides an acceptable fit to the data $\left(\chi^{2}=432.518, \mathrm{df}=223, \chi^{2} / \mathrm{df}=1.940\right.$, $\mathrm{GFI}=0.919$, RMSEA $=0.044$, TLI $=0.957$ and $\mathrm{CFI}=0.969)$. The estimation of the standardised coefficients indicates that the path between each construct was positive and significant $(\phi<0.001$ for all instances) in the research model. Specifically, the distributive justice, procedural justice and interactional justice have a significant positive influence on customer satisfaction. This shows that $H 1$ to $H 3$ are supported in this study. As for $H 4$, the results from Table III $(\beta=0.664, p<0.001)$ indicate that customer satisfaction has a significant positive influence on customer loyalty, thus supporting $H 4$.

As for H5, the moderating effect of whether the participants are local or international was conducted based on the suggestion by González-Romá, Peiró and Tordera (2002). For this method, the respondent was split into two groups, i.e. Malaysian and non-Malaysian (International).

To test the moderating effect of customer origin on the relationship between satisfaction and loyalty, a moderation test was run. The results from Table IV show that the Beta coefficients of the two groups of customers (Malaysian and International) were not significantly different; the $t$-values of the test was less than $1.96(t=-0.756)$. Therefore, it can be concluded that whether the tourist is Malaysian or international does not have any moderating effect on the relationship between satisfaction and loyalty.

\section{Discussion and implications of the study}

The findings provide several important theoretical and managerial insights into the tourism and hospitality setting. First, they indicate that perceived justices (i.e. distributive justice,

\begin{tabular}{lccc}
\hline & S.R.W & & Supported \\
Hypothesised path & $\beta$ & Critical ratio & \begin{tabular}{l} 
(Yes/No) \\
\hline H1. Distributive Justice $\rightarrow$ Customer Satisfaction
\end{tabular} \\
H2. Procedural Justice $\rightarrow$ Customer Satisfaction & 0.176 & $3.496^{*}$ & Yes \\
H3. Interactional Justice $\rightarrow$ Customer Satisfaction & 0.494 & $5.490^{*}$ & Yes \\
H4. Customer Satisfaction $\rightarrow$ Customer Loyalty & 0.664 & $7.307^{*}$ & Yes \\
\end{tabular}

Notes: ${ }^{*} p$-value $<0.001$. S.R.W $=$ standardised regression weight
Table IV.

\begin{tabular}{|c|c|c|c|c|c|}
\hline \multirow[b]{2}{*}{ Moderating effect } & \multicolumn{2}{|c|}{ Malaysian } & \multicolumn{3}{|c|}{ International } \\
\hline & Estimate & $\mathrm{P}$ & Estimate & $\mathrm{P}$ & $z$-score \\
\hline Satisfaction $\rightarrow$ Loyalty & 0.532 & 0.000 & 0.466 & 0.00 & $0-0.756$ \\
\hline
\end{tabular}

Notes: ${ }^{* * *} p$-value $<0.01 ;{ }^{* *} p$-value $<0.05 ;{ }^{*} p$-value $<0.10$ 
procedural justice and interactional justice) have a positive and direct effect on customer satisfaction. This scenario reveals that customers will be satisfied with the hotel if they feel that benefits from the hotel services have been restored to them in a rightful and fair manner. These benefits include various aspects in the service recovery process, such as monetary compensation, apology, free upgrade or replacement, etc. The remedy that comes with the benefits was argued to induce positive perception or fairness of the service performance (Llosa et al., 2007). Hence, the outcome of the study was found to be consistent with the evidence from previous literature (Chebat and Slusarczyk, 2005).

In line with the results from past studies, it was found that there is a strong and positive relationship between service recovery and customer satisfaction (Mansori et al., 2014; Tax et al., 1998). These studies also indicated that customer satisfaction is positively related to the level of service recovery effort.

In addition, procedural justice was found to have a significant and direct influence on customer satisfaction. This indicates that customer satisfaction is directly influenced by the underlying elements of procedural justice (i.e. a company's policies and rules). This aspect may include various rules and policies that affect customers such as flexibility, accessibility, process and decision controls, speed of response and acceptance of responsibility (Baloglu et al., 2010; Tax et al., 1998). All these activities are critical for influencing customers' evaluations of the service recovery outcome. The relationship between procedural justice and customer satisfaction is supported in previous studies (del Río-Lanza et al., 2009; Mattila and Patterson, 2004). Similarly, interactive justice was also found to have a significantly positive and direct influence on customer satisfaction. This demonstrates that customer satisfaction is directly influenced by the means of interaction; i.e. the degree of performance and behaviour of the firm's staff to provide service recovery for customers. The findings of this study are consistent with the evidence from past research (del Río-Lanza et al., 2009; McColl-Kennedy and Sparks, 2003).

This study further reaffirms the link between customer satisfaction and customer loyalty. Based on the statistical output, it was found that customer satisfaction proves to have a significantly positive and direct effect on customer loyalty. Zemke (1999) advocated that satisfaction and future loyalty of customers rely on whether they feel they were treated fairly. Thus, the hotel should quickly rectify the arising problem and conflict to let customers feel satisfied and loyal to the hotel. However, the difference between countries of origin (Malaysian verses international) does not play a moderating effect in the relationship between customer satisfaction and customer loyalty.

In the facet of managerial implication, service recovery has become very crucial to maintain great emotional connection with customers especially in this rapidly changing digital landscape when online platforms such as Agoda, Expedia and Trivago provide a platform for the customers to share their experiences, reviews and rate the service rendered from a particular premise. Given that, customers can post their discouraging reviews on the platforms and this will negatively affect the first impression of the potential customers. Getting things worse, customers also might shift to other alternative solution for accommodation provided by the disrupters such as Airbnb since the switching cost is almost zero. Airbnb's feature has further increased the fierce saturated competition and subsequently, customer satisfaction and loyalty becomes more significant. From the economic aspect, customer satisfaction and loyalty has great impact in tourism industry Malaysia because customer advocacy could increase the retention rate and customers will share their positive experiences on the social network.

Therefore, hotel managers and their immediate team should emphasise the importance of service recovery since it can reinstate customer service justice. For example, the 
IJQSS

11,2

management can consider effective recovery remedy by offering fair levels of compensation to customers as far as distributive justice is concerned. This compensation may include a free upgrade of the room or free meal coupon. As for the procedural justice aspect, it is suggested that the management of service firms should perform a psychological service recovery when there is a failure in their service delivery process. Friendly standard policies and rules must be in place to tackle such failures. For instance, if a hotel makes a mistake in the customer's room reservation or bill, the policies and rules should include a standard recovery procedure such as offering an apology with a detailed explanation and then immediately rectifying the mistake. By doing so, this can prevent customers from becoming dissatisfied with that particular hotel.

In addition, the management can improve the interactional justice as perceived by customers by maximising the effectiveness of staff when it comes to interpersonal skills of handling complaints. This can be done through intensive training and short courses which can develop staff knowledge and communication skills; particularly in handling service failures. Having good interpersonal skills can enhance the confidence of the staff, as well as improve the image of the firm. This will reflect on the level of professionalism in managing the service recovery, thus improving customer satisfaction. Even though ethnicity may not have a moderating role in the relationship between satisfaction and loyalty, understanding the importance of different nationalities and cultural beliefs will allow the business to create specific strategies to serve their customers in effective and efficient manners.

\section{Limitations and future research}

Several limitations were identified in the present study. The main limitation is related to the research setting; whereby, this research is limited to the hotel industry in Malaysia. The findings may not be the most accurate representation of the hospitability industry; application is subject to various contexts. Second, the questionnaire only consisted of close-ended questions. Realistic feedback and reasoning for the ratings made by respondents might not be accurately reflected upon given the restrictions in answering the questionnaire. To enhance the existing theory, future research should consider the role of service recovery, customer satisfaction and customer loyalty in the context of other service settings (e.g. retail, education, food and beverage). The triangulation approach as a base for the research method could be implemented to generate reliable findings in a more comprehensive way.

Another limitation of this study was the demographic characteristics of the sample. The respondents were relatively young and in the medium income bracket. Thus, the findings of this study may raise the issue of generalisation and might not be applicable to other research settings. Future studies should include inputs of respondents from other countries, educational backgrounds, age groups and income groups. Various cultures and demographic factors may have a different impact on service evaluation.

\section{Conclusion}

The results of this study suggest that service recovery is a complex process where each dimension (distributive justice, procedural justice and interactional justice) has a positive effect towards customer satisfaction. Customers perceive the three dimensions as a single dimension; any absence of dimensions can lead to customer dissatisfaction. In addition, customer satisfaction positively affects customer loyalty in hotel services, indicating that service recovery is important for not only restoring customer satisfaction but also improving customer loyalty. To encourage and ensure that 
customers revisit the same hotel, the services provided must meet their promise, and service failures should be kept in the minimal possible level. Only by doing so, customers will feel satisfied and loyal to the hotel. In conclusion, service recovery is important for restoring customer satisfaction and generating a positive influence on customer loyalty towards the hotel.

\section{References}

Anderson, E.W., Fornell, C. and Mazvancheryl, S.K. (2004), "Customer satisfaction and shareholder value", Journal of Marketing, Vol. 68 No. 4, pp. 172-185.

Baloglu, S., Erdem, M., Brewer, P., Mayer, K., Gyung Kim, M., Wang, C. and Mattila, A.S. (2010), “The relationship between consumer complaining behavior and service recovery: an integrative review", International Journal of Contemporary Hospitality Management, Vol. 22 No. 7, pp. 975-991.

Berezan, O., Raab, C., Yoo, M. and Love, C. (2013), "Sustainable hotel practices and nationality: the impact on guest satisfaction and guest intention to return", International Journal of Hospitality Management, Vol. 34, pp. 227-233.

Bitner, M.J., Booms, B.H. and Tetreault, M.S. (1990), "The service encounter: diagnosing favorable and unfavorable incidents", The Journal of Marketing, Vol. 54 No. 1, pp. 71-84.

Bugg Holloway, B., Wang, S. and Beatty, S.E. (2009), "Betrayal? Relationship quality implications in service recovery”, Journal of Services Marketing, Vol. 23 No. 6, pp. 385-396.

Chan, Y.Y. and Mansori, S. (2016), "Factor that influences consumers' Brand loyalty towards cosmetic products", Journal of Marketing Management and Consumer Behavior, Vol. 1 No. 1.

Chebat, J.-C. and Slusarczyk, W. (2005), "How emotions mediate the effects of perceived justice on loyalty in service recovery situations: an empirical study", Journal of Business Research, Vol. 58 No. 5, pp. 664-673.

Chien-Hsiung, L. (2011), "A study on the relationship between the brand image and customer satisfaction in the catering businesses", African Journal of Business Management, Vol. 5 No. 18, pp. $7732-7739$.

Choi, B. and Choi, B.-J. (2014), "The effects of perceived service recovery justice on customer affection, loyalty, and word-of-mouth”, European Journal of Marketing, Vol. 48 No. 1/2, pp. 108-131.

Clemmer, E.C. and Schneider, B. (1996), "Fair service", Advances in Services Marketing and Management, Vol. 5, pp. 109-126.

del Río-Lanza, A.B., Vázquez-Casielles, R. and Díaz-Martín, A.M. (2009), "Satisfaction with service recovery: perceived justice and emotional responses”, Journal of Business Research, Vol. 62 No. 8 , pp. 775-781.

Dolinsky, A.L. (1994), "A consumer complaint framework with resulting strategies: an application to higher education”, Journal of Services Marketing, Vol. 8 No. 3, pp. 27-39.

Fornell, C. and Larcker, D.F. (1981), "Structural equation models with unobservable variables and measurement error: algebra and statistics", Journal of Marketing Research, pp. 382-388.

Fornell, C., Johnson, M.D., Anderson, E.W., Cha, J. and Bryant, B.E. (1996), "The American customer satisfaction index: nature, purpose, and findings", The Journal of Marketing, Vol. 60 No. 4, pp. 7-18.

Forrester, W.R. and Maute, M.F. (2013), "The impact of relationship satisfaction on attributions, emotions, and behaviors following service failure", Journal of Applied Business Research (JABR), 17, Vol. 1.

Giese, J.L. and Cote, J.A. (2000), "Defining consumer satisfaction”, Academy of Marketing Science Review, Vol. 2000, pp. 1.
Malaysia's hotel industry 
IJQSS

11,2

González-Romá, V., Peiró, J.M. and Tordera, N. (2002), "An examination of the antecedents and moderator influences of climate strength", The Journal of Applied Psychology, Vol. 87 No. 3, p. 465.

Gounaris, S.P., Stathakopoulos, V. and Athanassopoulos, A.D. (2003), "Antecedents to perceived service quality: an exploratory study in the banking industry", International Journal of Bank Marketing, Vol. 21 No. 4, pp. 168-190.

Grönroos, C. (2007), Service Management and Marketing: customer Management in Service Competition, John Wiley and Sons.

Ha, J. and Jang, S.S. (2009), "Perceived justice in service recovery and behavioral intentions: the role of relationship quality", International Journal of Hospitality Management, Vol. 28 No. 3, pp. 319-327.

Hackl, P. and Westlund, A.H. (2000), "On structural equation modelling for customer satisfaction measurement”, Total Quality Management, Vol. 11 Nos 4/6, pp. 820-825.

Hair, J.F., Black, W.C., Babin, B.J., Anderson, R.E. and Tatham, R.L. (2006), Multivariate Data Analysis, Vol. 6, Pearson Prentice Hall Upper Saddle River, NJ.

Hart, C.W., Heskett, J.L. and Sasser Jr, W.E. (1989), “The profitable art of service recovery”, Harvard Business Review, Vol. 68 No. 4, pp. 148-156.

Hazée, S., Van Vaerenbergh, Y. and Armirotto, V. (2017), "Co-creating service recovery after service failure: the role of brand equity", Journal of Business Research, Vol. 74, pp. 101-109.

Hoffman, K.D. and Kelley, S.W. (2000), "Perceived justice needs and recovery evaluation: a contingency approach", European Journal of Marketing, Vol. 34 No. 3/4, pp. 418-433.

Hui, T.K., Wan, D. and Ho, A. (2007), "Tourists' satisfaction, recommendation and revisiting Singapore", Tourism Management, Vol. 28 No. 4, pp. 965-975.

Jacoby, J. and Chestnut, R.W. (1978), Brand Loyalty: Measurement and Management, John Wiley and Sons Incorporated.

Jones, H. and Farquhar, J.D. (2003), “Contact management and customer loyalty”, Journal of Financial Services Marketing, Vol. 8 No. 1, pp. 71-78.

Kandampully, J. and Suhartanto, D. (2000), "Customer loyalty in the hotel industry: the role of customer satisfaction and image", International Journal of Contemporary Hospitality Management, Vol. 12 No. 6, pp. 346-351.

Kim, T.T., Kim, W.G. and Kim, H.-B. (2009), "The effects of perceived justice on recovery satisfaction, trust, word-of-mouth, and revisit intention in upscale hotels", Tourism Management, Vol. 30 No. 1, pp. 51-62.

Komunda, M. and Osarenkhoe, A. (2012), "Remedy or cure for service failure? Effects of service recovery on customer satisfaction and loyalty", Business Process Management Journal, Vol. 18 No. 1, pp. 82-103.

Kuo, N.-T., Chang, K.-C., Cheng, Y.-S. and Lai, C.-H. (2013), "How service quality affects customer loyalty in the travel agency: the effects of customer satisfaction, service recovery, and perceived value”, Asia Pacific Journal of Tourism Research, Vol. 18 No. 7 , pp. 803-822.

Kuo, Y.-F. and Wu, C.-M. (2012), "Satisfaction and post-purchase intentions with service recovery of online shopping websites: Perspectives on perceived justice and emotions", International Journal of Information Management, Vol. 32 No. 2, pp. 127-138.

Liat, C.B., Mansori, S. and Huei, C.T. (2014), "The associations between service quality, corporate image, customer satisfaction, and loyalty: evidence from the Malaysian hotel industry", Journal of Hospitality Marketing and Management, Vol. 23 No. 3, pp. 314-326.

Lin, H.-H., Wang, Y.-S. and Chang, L.-K. (2011), "Consumer responses to online retailer's service recovery after a service failure: a perspective of justice theory", Managing Service Quality: An International Journal, Vol. 21 No. 5, pp. 511-534. 
Llosa, S., Orsingher, C., Aurier, P. and Siadou-Martin, B. (2007), "Perceived justice and consumption experience evaluations: a qualitative and experimental investigation", International Journal of Service Industry Management, Vol. 18 No. 5, pp. 450-471.

Mansori, S., Tyng, G.G. and Ismail, Z.M.M. (2014), "Service recovery, satisfaction and customers' post service behavior in the malaysian banking sector", Management Dynamics in the Knowledge Economy, Vol. 2 No. 1, pp. 5-20.

Mansori, S. and Vaz, A. (2014), "Service quality, satisfaction and student loyalty in Malaysian private education", available at: http://dx.doi.org/10.5539/ass.v10n7p57

Martínez-Tur, V., Peiró, J.M., Ramos, J. and Moliner, C. (2006), "Justice perceptions as predictors of customer satisfaction: the impact of distributive, procedural, and interactional Justice1", Journal of Applied Social Psychology, Vol. 36 No. 1, pp. 100-119.

Mattila, A.S. and Patterson, P.G. (2004), "Service recovery and fairness perceptions in collectivist and individualist contexts", Journal of Service Research, Vol. 6 No. 4, pp. 336-346.

Maxham, J.G. and Netemeyer, R.G. (2002), "Modeling customer perceptions of complaint handling over time: the effects of perceived justice on satisfaction and intent", Journal of Retailing, Vol. 78 No. 4, pp. 239-252.

McColl-Kennedy, J.R. and Sparks, B.A. (2003), "Application of fairness theory to service failures and service recovery”, Journal of Service Research, Vol. 5 No. 3, pp. 251-266.

Melián-González, S., Bulchand-Gidumal, J. and López-Valcárcel, B.G. (2013), "Online customer reviews of hotels as participation increases, better evaluation is obtained", Cornell Hospitality Quarterly, Vol. 54 No. 3, pp. 274-283.

Miller, J.L., Craighead, C.W. and Karwan, K.R. (2000), "Service recovery: a framework and empirical investigation”, Journal of Operations Management, Vol. 18 No. 4, pp. 387-400.

Mohajerani, P. and Miremadi, A. (2012), "Customer satisfaction modeling in hotel industry: a case study of Kish Island in Iran”, International Journal of Marketing Studies, Vol. 4 No. 3, p. 134.

Morgan, R.M. and Hunt, S.D. (1994), "The commitment-trust theory of relationship marketing", The Journal of Marketing, Vol. 58 No. 3, pp. 20-38.

Murphy, K., Bilgihan, A., Kubickova, M. and Boseo, M. (2015), "There is no 'T'in recovery: Managements' perspective of service recovery", Journal of Quality Assurance in Hospitality and Tourism, Vol. 16 No. 3, pp. 303-322.

Oliver, R.L. (1999), “Whence consumer loyalty?”, The Journal of Marketing, Vol. 63, pp. 33-44.

Pantouvakis, A. and Bouranta, N. (2013), "The link between organizational learning culture and customer satisfaction: confirming relationship and exploring moderating effect", The Learning Organization, Vol. 20 No. 1, pp. 48-64.

Ranaweera, C. and Prabhu, J. (2003), "The influence of satisfaction, trust and switching barriers on customer retention in a continuous purchasing setting", International Journal of Service Industry Management, Vol. 14 No. 4, pp. 374-395.

Reichheld, F.F., Markey, R.G., Jr. and Hopton, C. (2000), "The loyalty effect-the relationship between loyalty and profits", European Business Journal, Vol. 12 No. 3, pp. 134.

Ryu, K., Han, H. and Kim, T.-H. (2008), "The relationships among overall quick-casual restaurant image, perceived value, customer satisfaction, and behavioral intentions", International Journal of Hospitality Management, Vol. 27 No. 3, pp. 459-469.

Schoefer, K. and Ennew, C. (2004), "Customer evaluations of tour operators' responses to their complaints", Journal of Travel and Tourism Marketing, Vol. 17 No. 1, pp. 83-92.

Shah Alam, S. and Mohd Yasin, N. (2010), "What factors influence online Brand trust: evidence from online tickets buyers in Malaysia", Journal of Theoretical and Applied Electronic Commerce Research, Vol. 5 No. 3, pp. 78-89. 
IJQSS

11,2

Siu, N.Y.-M., Zhang, T.J.F. and Yau, C.-Y.J. (2013), "The roles of justice and customer satisfaction in customer retention: a lesson from service recovery", Journal of Business Ethics, Vol. 114 No. 4, pp. 675-686.

Skogland, I. and Siguaw, J.A. (2004), "Are your satisfied customers loyal?”, Cornell Hotel and Restaurant Administration Quarterly, Vol. 45 No. 3, pp. 221-234.

Sparks, B.A. and McColl-Kennedy, J.R. (2001), "Justice strategy options for increased customer satisfaction in a services recovery setting", Journal of Business Research, Vol. 54 No. 3, pp. 209-218.

Steenkamp, J.-B.E. and Geyskens, I. (2012), "Transaction cost economics and the roles of national culture: a test of hypotheses based on Inglehart and Hofstede", Journal of the Academy of Marketing Science, Vol. 40 No. 2, pp. 252-270.

Tax, S.S., Brown, S.W. and Chandrashekaran, M. (1998), "Customer evaluations of service complaint experiences: implications for relationship marketing", The Journal of Marketing, Vol. 62 No. 2, pp. 60-76.

Tse, D.K. and Wilton, P.C. (1988), "Models of consumer satisfaction formation: an extension”, Journal of Marketing Research, Vol. 25 No. 2, pp. 204-212.

UNWTO (2017), UNWTO Tourism Annual Report 2016, UNWTO.

Van Den Haak, T. (2015), Satisfaction and Loyalty in E-Commerce: The Moderating Role of Nationality Marketing Dynamism and Sustainability: Things Change, Things Stay the Same, Springer, p. 641.

Wen, B. and Geng-qing Chi, C. (2013), "Examine the cognitive and affective antecedents to service recovery satisfaction: a field study of delayed airline passengers", International Journal of Contemporary Hospitality Management, Vol. 25 No. 3, pp. 306-327.

WTTC (2016), Travel and Tourism Conomic Impact, World Travel and Tourism Council.

Zemke, R. (1999), Service Recovery: turning Oops into Opportunity. Best Practices in Customer Service, AMA Publications, New York, NY, pp. 278-279.

\section{Appendix. Measurement instrument}

Distributive justice

- The hotel manager was able to offer an appropriate compensation for the service failure.

- The quantum of compensation was adequate.

- The compensation offered by the hotel fulfilled my expectation.

- The compensation was offered in a sincere manner.

Proceduraljustice

- I was given an opportunity to express my complaint.

- The hotel has a proper procedure in handling my complaint.

- The hotel provided proper explanation to my complaint.

- The hotel responded promptly to my complaint.

Interactional justice

- The hotel demonstrated appropriate concern about my complaint.

- The hotel employees are well trained in handling service recovery.

- The hotel provided proper effort towards service recovery.

- I am satisfied with the hotel's overall service recovery actions to my complaint. 
- I was pleased to stay at this hotel.

- I really enjoyed myself at this hotel.

- My overall impression of this hotel was satisfactory.

- My overall impression of this hotel put me in a good mood.

Customer loyalty

- I consider myself to be a loyal guest of the hotel.

- I would not switch even if a competing hotel were to offer a better rate or discount on their services.

- I intend to use this hotel more often in the near future.

- I do not foresee myself switching to a different hotel as long as I travel to this area.

- I would highly recommend the hotel to my friends and family.

- I am likely to make positive comments about the hotel to my friends and relatives.

Corresponding author

Shaheen Mansori can be contacted at: shaheen_mansori@yahoo.com

For instructions on how to order reprints of this article, please visit our website: 